\title{
Pelanggaran Kode Etik Jurnalistik dalam Pemberitaan Anak di GTV
}

\author{
Natasya Feline Desvianny, Eko Harry Susanto \\ natasyafeline@gmail.com, ekos@,fikom.untar.ac.id
}

Fakultas Ilmu Komunikasi Universitas Tarumanagara

\begin{abstract}
The press is an organization for disseminating information through mass media, the more information received, the greater the responsibility required. In carrying out its functions, rights, obligations and role, the press is demanded to be open to the public about a news that is raised. To carry out good journalistic activities requires a journalistic code of ethics. The code of ethics established by the Press Council is a basic guideline / reference in carrying out journalistic activities. This regulation makes the direction for the press to continue in accordance with the rules, even though accessing news now is not only through the mass media such as television. Television is part of the mainstream media, despite the convergence of media, the audience still believes that journalistic news on television can be trusted with the truth and credibility of the news content. Reasearcher use descriptive qualitative methods to analyze in detail the problems that are formulated. The research is to find out how the application of the code of ethics in the production of television news on GTV. Because code of ethics is a basic reference in carrying out journalism activities, the purpose of journalism is the correctness of the information that will be received by the public.
\end{abstract}

Keyword: code of ethics, press, mass media, television.

\begin{abstract}
Abstrak
Pers merupakan alat penyebar informasi melalui media massa. Banyaknya informasi yang diterima, semakin tinggi tanggung jawab yang dibutuhkan. Untuk melaksanakan hak, fungsi, kewajiban, dan peranannya, pers dituntut harus terbuka kepada masyarakat terhadap sebuah berita yang diangkat. Untuk menjalankan kegiatan jurnalistik yang baik dibutuhkan adanya kode etik jurnalistik. Kode etik yang ditetapkan oleh Dewan Pers merupakan pedoman/acuan dasar dalam menjalani kegiatan jurnalistik. Peraturan inilah yang menjadikan arah agar pers tetap berjalan sesuai dengan aturan, meskipun mengakses berita kini tidak hanya melalui media massa seperti televisi. Televisi merupakan bagian dari media mainstream, meskipun adanya konvergensi media namun khalayak tetap memandang bahwa berita jurnalistik di televisi dapat dipercaya kebenaran serta kredibilitas isi berita tersebut. Penelitian ini menggunakan metode penelitian kualitatif deskriptif untuk menganalisis secara rinci masalah-masalah yang dirumuskan. Tujuan dari adanya penelitian ini ialah untuk mengetahui bagaimana penerapan dari kode etik dalam subuah produksi berita televisi di GTV. Karena kode etik merupakan acuan dasar dalam melaksanakan kegiatan jurnalisme, tujuan dari adanya jurnalisme adalah kebenaran dari sebuah informasi yang akan diterima oleh masyarakat.
\end{abstract}

Kata Kunci: kode etik, pers, media massa, televisi. 


\section{Pendahuluan}

Media elektronik seperti televisi adalah salah satu bentuk media massa. Media massa memiliki peran yang sangat penting untuk aspek kehidupan manusia. Menurut Suryawati (2011:45) Televisi ialah sebuah media komunikasi dengan sifatnya yang audio visual, merujuk pada penyajian berita yang berorientasi kepada reproduksi dari sebuah realita. Kekuatan utama media televisi berada pada pemilihan gambar dan pengisian suara. Sementara itu kelebihan televisi dibanding radio adalah sifatnya lebih audio visual. Tujuan utama masyarakat dalam menggunakan televisi pada umumnya ialah mendapatkan hiburan barulah kemudian untuk mendapatkan sebuah informasi.

Dewan Pers telah menetapkan bahwa jurnalis Indonesia harus mematuhi kode etik sebagai pedoman dalam mencari, menulis, dan melakukan penyebaran informasi kepada masyarakat.

Adapun seringkali kita temui contoh dari kasus pelanggaran di media yang melanggar kode etik jurnalistik yaitu penyebutan identitas anak di bawah umur, penayangan adegan sadis yang mengandung kekerasan fisik, dan menampilkan adegan cabul baik dalam bentuk foto, gambar, atau tulisan.

Definisi berita secara umum adalah peristiwa yang menarik pembaca. Berita adalah bentuk laporan dari sebuah informasi mengenai fakta yang terjadi atau isu dari sebuah peristiwa. Bentuk berita dapat dikategorikan menjadi soft news, hard news, feature, dan lan-lain.

Dough Newsom dan James A. Wollert dalam Sumadiria (2011:64) "Berita adalah apa saja yang ingin dan perlu diketahui orang banyak. Dengan melaporkan sebuah berita, media massa dapat memberikan informasi kepada khalayak yang lebih luas mengenai apa saja yang mereka butuhkan." Berita jurnalistik seperti umumnya melaporkan kejadian-kejadian besar seperti bencana alam dan politik.

Ujung tombak dalam kegiatan jurnalistik yang berperan sebagai penyebar informasi ialah pers sendiri dan sebagai lembaga sosial dalam adanya kegiatan dunia jurnalistik yang bertanggung jawab untuk mencari, meliput, menulis, menyiarkan, menyebarkan informasi kepada khalayak baik dalam bentuk gambar, video, atau artikel di media elektronik atau di dalam media massa lainnya.

Kode etik jurnalistik dibuat sebagai pedoman bagi jurnalis dan industri media massa. Kode etik jurnalistik seharusnya dipahami oleh pekerja media sebagai landasan dalam menjalankan tugas nya. Tidak hanya Kode Etik Jurnalistik masih terdapat aturan lain atau perundangan-undangan yang berlaku seperti Etika dan standar penyiaran dalam Undang-Undang Penyiaran No. 32 Tahun 2002, Peraturan KPI No. 02/P/KPI/12/2009 tentang P3, serta Peraturan KPI No.03/P/ KPI/12/2009 tentang SPS (Kurniadi, 2013).

Dalam industri televisi, P3SPS atau Pelaku Pedoman Penyiaran diadopsi dari kode etik jurnalistik agar menciptakan tayangan yang sehat bagi publik, dalam tayangan siaran jurnalistik tidak boleh ada kebohongan dan rekayasa, namun peraturan yang dibuat bukan untuk membatasi ruang gerak dari kreativitas pers, peraturan tersebut justru dibuat agar mengembangkan kreativitas tanpa melupakan norma-norma yang telah ditetapkan.

Pada penelitian ini, peneliti meneliti pelanggaran kode etik jurnalistik pada tayangan berita di GTV dengan menganalisis salah satu berita yang tayang pada 
11 Januari 2020 dan bagaimana penerapannya pada saat produksi berita berlangsung.

Berdasarkan latar belakang di atas, identifikasi masalah pada penelitian ini adalah masih terjadinya pelanggaran terhadap penerapan kode etik jurnalistik pada tayangan berita GTV; bagaimana bagaimana penerapan kode etik pada tim produksi GTV; bagaimana penerapan kode etik dalam produksi berita. Dengan demikian, permasalahan yang akan dibahas ialah: Bagaimana penerapan kode etik jurnalistik pada tayangan berita GTV.

Berdasarkan rumusan masalah di atas, maka tujuan dilakukan penelitian ini adalah untuk mengetahui apakah adanya pelanggaran terhadap penerapan kode etik jurnalistik pada tayangan berita GTV, untuk mengetahui proses penerapan kode etik pada tim produksi GTV, dan untuk mengetahui bagaimana GTV memberikan pembekalan kepada jurnalisnya

Peneliti berharap dengan dilakukan penelitian ini dapat memberikan manfaat bagi berbabai pihak yang membutuhkan. Adapun manfaat penelitian ialah memperluas wawasan tentang dunia jurnalistik dalam media massa yang memiliki hubungan dengan etika jurnalistik. Melalui penelitian ini peneliti juga berharap dapat mengevaluasi dan memberi masukan untuk media-media nasional agar lebih memperhatikan kode etik jurnalistik yang berlaku.

\section{Metode Penelitian}

Pada penelitian ini, penulis menggunakan metode peneltian kualitatif bersifat deskriptif. Denzin dan Lincoln (Moelong 2009:5) bahwa penelitian kualitatif ialah sebuah metode yang mengungkapkan latar ilmiah, dengan maksud agarmenafsirkan fenomena yang terjadi dan dilakukan dengan melibatkan berbagai metode.

Penggunaan metode deskriptif bertujuan untuk menganalisis secara rinci mengenai masalah yang akan diteliti, menurut Whitney (Nazir, 2011:6) metode deskriptif adalah pencarian fakta dengan interpretasi yang tepat. Penelitian ini mempelajari bagaimana penerapan kode etik dalam tayangan program berita dalam televisi termasuk proses yang berlangsung dan yang mempengaruhinya.

Berdasarkan pengertian diatas, penulis menggunakan penelitian deskriptif lantaran di dalam penelitian ini penulis menemukan bahwa agar permasalahan yang dilakukan pada penelitian yang hendak ditelititi ini dapat di deskripsikan terkait penerapan kode etik dalam tayangan berita di GTV.

\section{Teknik Pengolahan dan Analisis Data}

Menurut Emzir (2012:85) Analisis data adalah sebuah cara sistematis dalam melakukan pencarian dan pengaturan dalam transkrip wawancara, catatan di lapangan, dan materi yang telah dikumpulkan untuk memberikan pemahaman penulis sendiri mengenai isi materi tersebut dan memungkinkan peneliti menyajikan data sudah anda temukan pada orang lain.

Model analisis penelitian kualitatif ini berdasarkan pendapat Miles dan Huberman (1992:15-16) menyatakan proses analisis data kualitatif itu melalui tiga tahap, yaitu: 1). Adanya reduksi data sebagai sebuah proses pertama dari pemilihan, memusatkan perhatian dengan cara sederhana, secara abstrak dan transformasi data kasar yang muncul dari catatan-catatan dilapangan. 2). Penyajian data dilakukan untuk mencari sekumpulan informasi tersusun yang memberi kemungkinan adanya penarikan kesimpulan dan pengambilan tindakan. Penciptaan dan penggunaan 
penyajian data tidaklah terdpisah dari analisis. 3). Dengan menarik sebuah kesimpulan atau verifikasi dalam tahap ketiga merupakan permulaan dari pengumpulan data, seorang penganalisis penelitian kualtitatif mulai mencari arti benda-benda, mencatat keteraturan, pola-pola, penjelasan, konfigurasi alaur sebab akibat dan proposisi. (Susanto 2018:69).

\section{Hasil Penemuan dan Diskusi}

Penulis melakukan penelitian dan wawancara semi terstruktur dengan narasumber yang telah dipilih oleh penulis, setelah melakukan penelitian, penulis mendapatkan hasil berupa data yang menjawab pertanyaan dari rumusan masalah di atas. Menurut hasil riset melalui wawancara, data pertama yang didapatkan ialah masih terjadi adanya pelanggaran dalam tayangan berita di GTV.

Gambar 1. Pelanggaran Tayangan Berita di GTV

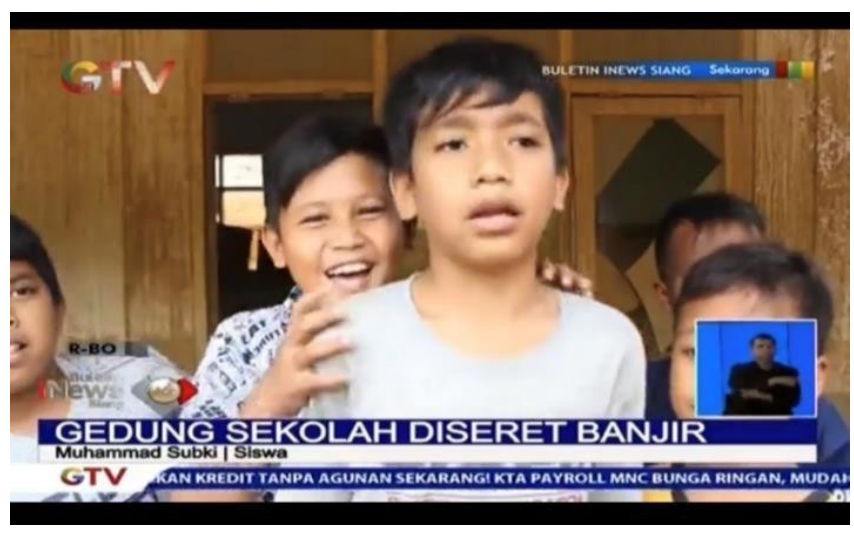

Sumber: Dokumentasi Peneliti

Media mainstream seperti televisi masih menjadi acuan untuk khalayak dalam mengonsumsi berita, biasanya khalayak umum menjadikan berita di televisi untuk memverifikasi sebuah informasi yang tersebar melalui media baru seperti media online.

Namun, dalam praktiknya terkadang tayangan televisi pun masih melanggar kode etik jurnalistik yang diatur sesuai dengan standar program siaran seperti P3 dan SPS dalam Pedoman Program Penyiaran dan Standar Program Siaran (P3SPS) dan UU No. 32 Tahun 2002 tentang Penyiaran.

Dengan mematuhi kode etik jurnalistik, maka berita tersebut dapat dipertanggung jawabkan, selain itu kode etik jurnalistik juga merupakan ramburambu bagi pers agar tetap berjalan sesuai peraturan dan menghindari berita yang tidak layak untuk diberitakan kepada khalayak.

Penulis menemukan bahwa pelanggaran dalam salah satu berita yang tayang pada 11 Januari 2020, pelanggaran ini terjadi karena adanya perbedaan interpretasi oleh GTV dalam menafsirkan kode etik jurnalistik yang sesuai dalam P3SPS. Pada tayangan tersebut telah mewawancarai anak dibawah umur yang merupakan korban bencana banjir dari sekolah yang hanyut terseret banjir di Lebak, Banten. Berdasarkan peraturan KPI peliputan bencana dilarang mewawancarai anak dibawah umur sebagai narasumber. 
Sumber berita memang penting untuk suatu berita. Jika ingin memakai narasumber, wartawan harus mencari sumber yang layak untuk memenuhi syarat. Isi sebuah berita dapat dikatakan berkualitas bila dapat memenuhi standar penyiaran. Standar yang dipakai, yakni, akurasi, kapabilitas dari seorang narasumber, seimbang dan adil, obyektif penekanan dan padat, dan menarik.

Penerapan kode etik jurnalistik di GTV tidak hanya berlaku bagi wartawan namun juga di setiap lini organisasi. Menurut UU No. 40 tahun 1999, Kode Etik Jurnalistik adalah kode etik yang disepakati organanisasi wartawan dan ditetapkan oleh Dewan Pers.

Pada hakikatnya ada empat asas dalam KEJ, yaitu (1) Asas moralitas, adalah nilai-nilai moral yang terkandung didalamnya, (2) Asas profesionalitas, adalah meliputi pemberitaan yang akurat, faktual, jelas sumbernya, dengan dapat membedakan fakta dan opini, serta tidak membuat berita bohong dan fitnah, menghargai off the record dll, (3) Asas demokratis, wartawan harus bertindak adil dan berimbang dalam pemberitaan (4) Asas Supremasi Hukum, yaitu bahwa wartawan tidak boleh melakukan plagiat, menghormati asas praduga tidak bersalah, memiliki hak tolak dan tidak menyalahgunakan profesinya (Eko, Susanto, \& Si, 1945). Penerapan ini penting untuk dipahami dan diberlakukan bagi setiap jurnalisnya tidak hanya wartawan yang meliput berita, karena dalam sebuah tayangan berita itu melalui tiga tahap yaitu pra produksi, produksi, dan pasca produksi. Ketiga tahap tersebut dalam program berita dimana melibatkan banyak orang dari setiap divisi termasuk editing, para tim redaksi, dan tim produksi.

Dalam menjalankan kegiatan jurnalistik untuk mewujudkan sebuah kemerdekaan pers, jurnalis Indonesia perlu juga menyadari adanya kepentingan dan tanggung jawab bagi bangsa. Idealnya, jurnalistik sebagai penyebar sebuah informasi ikut mencerdaskan bangsa. Dalam menerapkan etika jurnalistik yang baik, GTV secara rutin memberikan pembekalan kepada redaksi dan wartawan. Pembekalan ini merupakan bentuk dari pelatihan kode etik untuk memberikan pengetahuan, skill dan keterampilan dalam jurnalistik.

Pembekalan sebagai bentuk pelatihan yang diberikan kepada para wartawan dan redaksi agar mengasah dan menumbuhkan sikap jurnalistik yang sesuai dengan kode etik agar berita yang dimuat dapat dapat dipertanggungjawabkan. Pembekalan yang diberikan oleh GTV ialah melalui training yang khusus tentang dunia jurnalistik seperti IJTI, KPI, AJI, dan KOMINFO. Bahkan GTV pun melakukan in- housetraining kepada tim redaksi untuk mengasah dalam penulisan naskah, editing, dan sensoring.

Pada tahap pra produksi merupakan tahap awal dari siaran, dalam tahap ini perencanaan produksi seperti ide dan gagasan masih dalam bentuk naskah. Tahap produksi yaitu upaya untuk membuat naskah dijadikan dalam bentuk audio-visual. Tahap pasca produksi ini merupakan tahap akhir dimana penyelesaian meliputi editing, sensoring, pengisian suara untuk naskah berita dan mengevaluasi. Tahap akhir merupakan bagian terpenting dimana pengakurasian fakta dan penyeleksianisi berita akan diperiksa kembali.

\section{Simpulan}

Berdasarkan hasil penelitian yang sudah dikerjakan oleh peneliti tentang penerapan kode etik jurnalistik, berikut kesimpulan yang dibuat oleh penulis:

1. Terdapat adanya pelanggaran dalam tayangan berita jurnalistik yang 
disiarkan oleh GTV. Hal tersebut terjadi karena di dalam salah satu paket berita, pemberitaannya mewawancarai anak dibawah umur yang juga merupakan korban dari bencana banjir yang menyeret sebuah sekolah, pelanggaran tersebut diakui terjadi karena adanya perbedaan interpretasi dalam menafsirkan kode etik jurnalistik dalam P3SPS.

2. GTV adalah salah satu i media besar yang memiliki kredibilitas dalam pemberitaan jurnalistik. Hasil wawancara menunjukkan, bahwa hal ini dipengaruhi oleh penerapan kode etik tersebut. Penerapan kode etik jurnalistik diberlakukan pada setiap lini dalam organisasi, karena di dalam tayangan berita melalui tiga tahap yang melibatkan banyak orang, yaitu: pra produksi, produksi, dan paca produksi.

3. Penerapan kode etik jurnalistik dapat dijalankan jika adanya pembekalan yang diberikan oleh media tersebut. Pembekalan merupakan bentuk dari pelatihan yang dapat membimbing jurnalis untuk tetap berjalan sesuai dengan fungsi, hak, kewajiban, dan peranannya. Hasil penelitian menyatakan bahwa GTV aktif memberikan pembekalan secara keseluruhan tidak hanya kepada jurnalis. Tidak hanya mengikuti training khusus yang diberikan oleh lembaga seperti KOMINFO, JTI, AJI, dan sebagainya, tetapi GTV pun memberikan in-house-training untuk membekali kegiatan jurnalistik di medianya.

\section{Ucapan Terima Kasih}

Segala Puji dan Hormat penulis panjatkan kepada Tuhan Yesus Kristus atas kasih, anugerah dan penyertaan-Nya sehingga penulis sanggup untuk melaksanakan penelitian hingga menyelesaikan penulisan jurnal ini. Penulis juga berterima kasih kepada orang tua serta keluarga dan kepada seluruh narasumber yang terlibat dalam penelitian ini. Penulis berharap jurnal penelitian ini dapat memberikan banyak manfaat dan wawasan bagi berbagai pihak. Akhir kata penulis ucapkan terima kasih.

\section{Daftar Pustaka}

Emzir. (2012). Metodologi Penelitian Kualitatif: Analisis Data. Jakarta: Rajawali Pers

Kurniadi, O. (2013). Budaya Jurnalistik Di Metro Tv. Jurnal Kajian Komunikasi, 1(2), 133-140. https://doi.org/10.24198/jkk.vol1n2.3

Nazir, Mohamad. (2011). Metode Penelitian. Bogor: Ghalia Indonesia.

Sumadiria, H.A.S. (2011). Jurnalistik Indonesia Menulis Berita Dan Feature, Panduan Praktis Jurnalis Profesional. Jakarta: Simbiosa Rekatama Media

Suryawati, Indah. (2011). Jurnalistik : Suatu Pengantar. Bogor : PT. Ghalia Indonesia.

Susanto, Eko Harry. (2018). Komunikasi Manusia: Teori dan Praktik Dalam Penyampaian Gagasan. Jakarta: Mitra Wacana Media 